\title{
Alcuíno
}

Três livros sobre a fé na santa e indivisível Trindade. Ao glorioso imperador Carlos Magno a Deus devoto*

Tradução de

Carlos Arthur R. Nascimento**

\section{LIVRO I}

\section{Prefácio}

Em nome da santa Trindade. Embora estejamos afastados da alegria da felicidade bem-aventurada na cegueira deste exílio, como pena justíssima pelo pecado original, não estamos de tal modo cortados e separados dela que mesmo, no que é mutável e temporal, não saibamos buscar ou desejar a eternidade, a verdade, a felicidade. $\mathrm{O}$ que se percebe pelo fato de que não temos vontade nem de morrer, nem de nos enganar, nem de estar na miséria. Donde, por este instinto natural, é comum aos homens querer ser felizes, embora o desejo da felicidade se encontre de modo diverso no espírito de cada um. De fato, alguns julgam que ser feliz é apoderar-se do reino terreno; outros, ter riquezas em abundância; outros, ser elevado às honras; outros, porém, alegram-se por serem cobertos de louvores; outros, anseiam pelos prazeres carnais. Ora, a verdadeira felicidade não pode de modo nenhum ser encontrada na volubilidade desta vida. Acerca do que somos admoestados, pelo curso inteiro das Sagradas Escrituras, a que nos elevemos do que é terrestre para o celeste, onde está a verdadeira e eterna felicidade; a qual, é mais do que certo, que ninguém pode chegar, senão pela fé da paz católica, com a cooperação da caridade de Deus e do próximo.

\section{Capítulo I \\ Que ninguém poderá chegar à verdadeira felicidade, senão pela fé católica}

Em suma, aos que desejam chegar à verdadeira felicidade, a fé é necessária antes de tudo, como ensina a autoridade apostólica ao dizer: "Sem fé é impossivel

* PL 101, Tomo 2, Col. 15-15 (n 705-708)
UNICAMP

VERITAS

Porto Alegre

v. 41

nㅇ 163

Setembro 1996

p. $553-557$ 
agradar a Deus" (Hebr. XI, 6). Consta, portanto, que ninguém pode chegar à verdadeira felicidade, a não ser que agrade a Deus; ora, ninguém pode agradar a Deus, senão pela fé. Pois a fé é o fundamento de todos os bens. A fé é início da salvação humana; sem ela ninguém pode chegar à comunidade dos filhos de Deus, pois, sem ela, ninguém consegue, neste mundo, a graça da justificação, nem possuirá, no vindouro, a vida eterna. $\mathrm{E}$ se alguém não caminhar aqui pela fé, não chegará à manifestação da visão feliz de Nosso Senhor Jesus Cristo. Por conseguinte, toda alma racional, na idade adequada, instrua-se na fé católica, especialmente os pregadores do povo cristão e os doutores das igrejas de Deus, para que possam resistir aos contraditores da verdade e ser de proveito aos amantes da paz católica. Como alguém ensinará o que não aprendeu? Ou, como poderá ser pastor se não sabe alimentar com o pão da vida o rebanho a si confiado? Que o ignorante não se envergonhe em aprender o que ignora e que aquele que sabe não seja lento em ensinar o que aprendeu. Saibam ambos que prestaram conta do dinheiro recebido a seu Senhor. Então o servo fiel ouvirá a esperada voz do Senhor dizer: "Muito bem, servo bom e fiel, porque foste fiel sobre pouco, te estabelecerei sobre muito, entra na alegria do Senhor teu Deus" (Mat. XXV, 21).

\section{Capítulo II}

\section{Sobre a unidade da Trindade da unidade}

Assim, toda a escritura do Antigo e do Novo Testamento divinamente inspirada, se catolicamente entendida, declara que o Pai, o Filho e o Espírito Santo são um Deus uno da mesma substância, de uma única essência e de uma unidade inseparável na divindade. Portanto, não são três deuses, mas um Deus Pai, Filho e Espírito Santo, embora o Pai tenha gerado o Filho e, assim, o Filho não seja quem é o Pai; o Filho seja gerado, e assim, o Pai não seja quem é o Filho; e o Espirito Santo não seja nem o Pai nem o Filho, mas apenas Espírito do Pai e do Filho, também ele co-igual ao Pai e ao Filho e pertencente à unidade da Trindade. Esta Trindade é um Deus uno de quem tudo procede, de acordo com o testamento do bemaventurado apóstolo Paulo, onde diz: "Porque a partir dele, por ele e nele tudo é, a ele e nele tudo é, a ele glória nos séculos dos séculos" (Rom. XI, 36). Sustentemos, pois, com toda firmeza a que o Pai, o Filho e o Espírito Santo são um Deus uno quanto à natureza; no entanto, o próprio Pai não é quem é o Filho, nem o próprio Filho é quem é o Pai, nem o próprio Espírito Santo é quem é o Pai ou o Filho. De fato, é uma a essência do Pai e do Filho e do Espirito Santo. Na qual não é um o Pai, outro o filho e outro o Espírito Santo; embora, quanto à pessoa, o Pai seja um, outro o Filho e outro o Espírito Santo. O que nos é mostrado especialmente no próprio início das Sagradas Escrituras, onde Deus diz: "Façamos o homem à nossa imagem e semelhança" (Gen. I 26). De fato, como disse "imagem" no número singular, mostrou que há uma natureza una, a cuja imagem o homem seria feito. Mas, quando diz no plural "nossa", mostra que Deus, a cuja imagem fazia o homem, não é uma pessoa. Com efeito, se aquela essência una do Pai, do Filho e do Espírito Santo fosse uma pessoa una, não se diria "à nossa imagem", mas "à minha imagem"; nem diria "façamos", mas "farei". Se, porém, se devesse entender ou crer três substâncias naquelas três pessoas, não se diria "à nossa imagem", mas "às nossas 
imagens". Ora, diz-se o homem feito a uma imagem de um Deus, para declarar a divindade una, quanto à essência, da Santa Trindade. Também o profeta Isaías não calou esta Trindade das pessoas e unidade da natureza revelada a ele, quando diz que viu os Serafins gritando: "Santo, Santo, Santo o Senhor Deus Sabaot" (IS. VI). Aí, sem dúvida, por se dizer três vezes "Santo" conhecemos a Trindade das pessoas, e por se dizer uma só vez "Senhor Deus Sabaot", a unidade da natureza divina. Claramente, sem nenhuma dúvida, deve-se crer que o Pai, o Filho e o Espírito Santo são um Senhor, onipotente, eterno, imutável. Cada um destes é Deus e todos, simultaneamente, um Deus e, não importa qual deles é substância plena, perfeita e eterna. Pois, tudo o que é o Pai, pelo que é Deus, pelo que é substância, pelo que é eternidade, isto é o Filho e o Espírito Santo. Igualmente, também o Filho, pelo que é Deus, pelo que é substância, pelo que é eternidade, isto é o Pai e isto é o Espírito Santo. E tudo que o Espírito Santo é, pelo que é Deus, pelo que é substância, pelo que é eternidade, isto é o Pai e o Filho, uma divindade nos três, uma essência, uma onipotência e tudo o que pode ser dito substantivamente de Deus. Se acaso fores interrogado acerca apenas do Pai, o que é o Pai? Responde: Deus. Interrogado acerca do Filho, responde: Deus. Interrogado acerca do Espírito Santo, responde: Deus. Se fores interrogado simultaneamente acerca do Pai, do Fjlho e do Espirito Santo, responde: não deuses, mas Deus, uno, onipotente, imutável.

\section{Capítulo III}

\section{Que algo é dito de Deus substancialmente e algo relativamente}

Cumpre saber que algo é dito de Deus substancialmente, como é o caso de Deus, grande, onipotente e tudo o que é dito para si, isto é, significando a substância da divindade. Por outro lado, algo é dito relativamente, como o Pai para o Filho, o Filho para o Pai e o Espírito Santo relativamente ao Pai e ao Filho. No entanto, para si, quer o Pai, quer o Filho, quer o Espírito Santo é dito Deus. Portanto, o Pai pelo que é Deus, por isto mesmo é substância. Visto que o filho é da mesma substância, sem dúvida também o Filho é Deus e o Espírito Santo é Deus. Mas, Deus, pelo que é Pai, se diz relativamente, pois não é nome de substância, mas refere-se ao Filho. Assim, não dizemos que o Filho é o Pai, como dizemos que o Filho é Deus; nem também dizemos que o Pai é o Filho, assim como dizemos que é Deus, pois Deus se diz substancialmente. O Pai, o Filho e o Espirito Santo se dizem relativamente.

\section{Capitulo IX \\ Que nada é dito em Deus de acordo com o acidente}

De fato, nada é dito em Deus de acordo com o acidente, pois nele nada é mutável. No entanto, nem tudo que é dito de Deus, é dito de acordo com a substância, como dizemos acima. De fato, embora o Pai seja dito para o Filho e o Filho para o Pai de acordo com o "para algo", não é acidente para o Pai, ser Pai, ou para o Filho, ser Filho, pois tanto aquele sempre é Pai como este sempre é Filho, pois a eternidade e a incomutabilidade nega a instabilidade de algum acidente em Deus, pois, todo o acidente, ou pode ser ou não ser, ou pode, ou então poderá de acordo 
com o tempo; pois, o Pai jamais foi não Pai, e o Filho jamais não Filho; nem jamais o Pai começou a ser Pai, nem o Filho a ser Filho, se em algum momento, o Pai começasse a ser Pai, ou o Filho a ser Filho, ou deixasse de ser o que era, o Pai ou o Filho seria dito de acordo com o acidente. Se, porém, o ser dito Pai, fosse dito para si mesmo, não para o Filho e o ser dito Filho, fosse dito para si mesmo, não para o Pai, sê-lo-ia dito de acordo com a substância. Ora, o Pai não é dito Pai senão pelo fato de que o Filho é para ele e o Filho não é dito Filho senão pelo fato de que tem um Pai. Não de acordo com a substância, como foi dito anteriormente, pois nenhum deles é dito isto para si mesmo, mas reciprocamente e um para o outro. Não porém de acordo com o acidente, pois tanto o ser dito Pai e o ser dito Filho é para eles eterno e incomutável.

\section{Capítulo XV \\ Como devem ser entendidas as locuções dos predicamentos acerca de Deus}

São dez os gêneros da locução humana pelos quais os seres humanos costumam comparar entre si seus sentimentos. Não falo daqueles que os gramáticos chamam de partes da oração, mas daqueles que os filósofos costumam denominar categorias e predicamentos em latim. Os quais recebem deles os seguintes nomes: substância, quantidade, qualidade, para algo, que é dito o gênero relativo de locução; também hábito, situação, tempo, lugar, fazer, sofrer. Estas são, pois, as causas de nossa locução. De fato, ou falamos da substância de qualquer coisa, ou da quantidade, isto é, da grandeza, ou também da qualidade, no qual gênero de locução dizemos bons, os que são bons, ou então para algo, isto é, quando pessoas quaisquer comparam-se entre si, como não se diz senhor a não ser que se entenda um servo, nem também servo a não ser que se refira a um senhor; também freqüentemente nossa fala mostra acerca do hábito da alma ou do corpo; ou acerca da situação em que se considera o estar de pé, sentar-se, jazer; acerca do lugar e do tempo, isto é, em qual lugar ou tempo se dá algo; também o que faz ou que sofre alguém. Portanto, de todos estes modos a Sagrada Escritura costuma falar de Deus, mas às vezes de modo próprio, às vezes por transposição e às vezes de modo relativo. De modo próprio Deus é uma substância una, suprema e infalível que sempre é o mesmo que é, à qual nada poderá inerir de adveniente ou de recendente, que sempre é o que é, pois é sempre imutável. Também Deus é dito grande, não através de outra grandeza, senão porque ele próprio é grande e imenso. Portanto, é grande através daquela grandeza pela qual ele próprio é a mesma grandeza, e é bom através daquela bondade pela qual ele próprio é a bondade. Nem para Deus o ser é distinto do ser grande e do ser bom; mas, por ser, é grande e é bom. Assim, não é adequado dizer acerca de Deus, nem três substâncias, nem três grandes, nem três bons. O que, porém, se diz fazer, diz-se verdadeirissimamente de Deus, por quem tudo o que é foi feito, ao dizer o Senhor: "Meu Pai opera até agora e eu opero" (Jo 5, 17). Isto é dito de Deus de modo próprio nos predicamentos acima nomeados se é que algo pode ser dito de modo próprio a respeito dele pela boca do ser humano. O Pai, o Filho e o Espírito Santo é dito de Deus de modo relativo, assim como ensinamos abundantemente acima. Mas, a situação, o 
hábito, os lugares, os tempos e o sofrer não são ditos de modo próprio em Deus, mas de modo transposto e por similitudes. Pois, é dito que "se assenta sobre os querubins" (S1. 79,2), o que se refere à situação; que "está envolvido pelo abismo como por uma vestimenta" (S1. 103, 6), o que se refere ao hábito; que "teus anos não desfalecem" (S1. 101, 28) o que se refere ao tempo; que "se eu subir ao céu tu ali estarás" (S1. 138, 8), o que se refere ao lugar. É dito também de Deus "Lamento ter feito o ser humano" (Gn. 6,7) ou também "Agüentando trabalhei". Com efeito, Deus não sofre nada quanto ao que se refere à substância de Deus, pois é Deus por ser uma substância incomutável e impassivel, enquanto todas as outras substâncias recebem acidentes pelos quais se dá nelas ou grande ou não importa qual mutação. A Deus, porém, algo de tal não pode acontecer e por isso a única substância ou essência incomutável é a que é Deus. Ao qual, na verdade, o próprio ser, donde a essência é denominada, cabe-lhe ao máximo e verdadeirissimamente; ao qual somente convém otimamente aquele nome pelo qual os gregos dizem IV e os latinos EST, como diz o Apóstolo: Não há nele ser e não, mas há nele ser. No entanto, a sublimidade desta discussão tão árdua já adverte aquele que escreve que tome um pouco de fôlego a fim de que passe a expor o que deve ser dito em seguida com o pensamento mais livre. 